\section{God bok for alle på akuttmottaket}

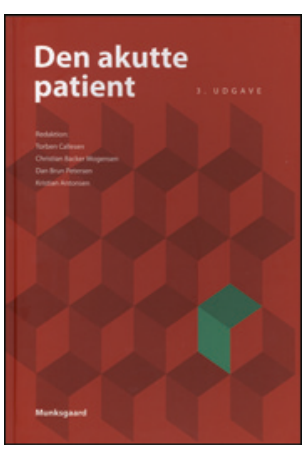

Torben Callesen, Christian Backer Mogensen, Dan Brun Petersen et al, red. Den akutte pasient

3. utg. 480 s, tab, ill. København: Munksgaard, 2016. Pris DKK 575

ISBN: 978-87-628-1417-2

Dette er tredje utgave av en lærebok beregnet for medisinstudenter og de yngste legene i akuttmottaket. Den internasjonale interessen for fremskutt kompetanse ved mottak av akuttinnlagte pasienter er økende, og denne utgivelsen understøtter denne interessen. Målgruppen er tydelig: mottakende leger. Mye av den akutte delen av den samlede medisinen er presentert i de 32 kapitlene. Unntatt er traumer, pediatri og kirurgi hvor det henvises til annen litteratur.

De ulike kapitlene er bygd opp både tradisjonelt etter diagnoser, men også etter symptompresentasjoner, for eksempel ABCDE-regelen. Sistnevnte omfatter for eksempel avsnitt om åndenød og endret bevissthetsnivå, noe som gjør at boken også kan fungere som en akutt oppslagsbok - ikke bare som en lærebok. Særlig verdifullt synes jeg det er at man oppsummerer tidsmessig hva man skal gjøre/ ha gjort de første fire timene etter mottak av pasientene. Dette fungerer som en sjekkliste og er alltid nyttig. Nytt i denne utgaven er et eget avsnitt om ultralydundersøkelser som forventes å bli et viktig diagnostisk hjelpemiddel for leger i akuttmottakene. I avsnittet om hudsykdommer er det mange fine illustrasjoner som gir pedagogisk støtte til forståelsen.

De fleste tilstandene er omtalt på en slik måte vi vil behandle det her i Norge. Skulle jeg påpeke potensielle forbedringspotensialer, kunne det vært å skille bedre mellom akutte og kroniske dysnatremier. Her bærer fortsatt omtalen preg av at man behandler kroniske forstyrrelser (varighet $>48$ timer), hvor den endokrinologiske tilnærmingen er vanligst, med forsiktig korreksjon av frykt for osmotisk demyeliniseringssyndrom. Her savner jeg den overgripende akuttmedisinske føringen om at «natriumforstyrrelser skal korrigeres i samme hastighet de oppstår». I tillegg kunne man vært flinkere, i stikkordregisteret, til å presisere hovedsiden tilstanden er omtalt på. Det blir fort leting mellom flere sider. I avsnittet om lungeemboli skriver man at en arteriell blodgass ofte er normal - noe jeg synes knapt forekommer. Det er her heller ikke omtalt bruk av ultralyd/ ekkokardiografi i diagnostikk av større lungeembolier, men blar man frem til avsnittet om ekkokardiografi, finnes omtale ved lungeemboli. Her bør det redigeres bedre.

Boken er skrevet på dansk, som jo er vårt opprinnelige skriftspråk, og er således lett å lese. Disposisjonen bidrar også til en lettlest tekst. Boken er god og kan anbefales alle som satser på en sannsynlig ny norsk spesialitet knyttet til akuttmottak, eller som av andre grunner ønsker å fokusere på - og forbedre - sitt eget i legearbeid i akuttmottaket.

\section{Dag Jacobsen}

Avdelingsleder, Akuttmedisinsk avdeling

Oslo universitetssykehus

\section{Kortfattet innføring i endokrinologi}

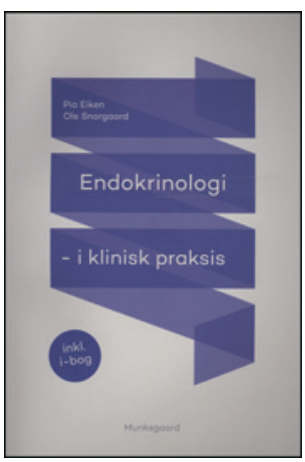

Pia Eiken, Ole Snorgaard

Endokrinologi i klinisk praksis

246 s, tab, ill. København: Munksgaard, 2016.

Pris DKK 275

ISBN 978-87-628-1383-0

I denne lettleste og kortfattede danske boken om endokrinologi henvender forfatterne seg til sykepleiere og yngre leger som ikke primært jobber med endokrinologiske problemstillinger, men som ønsker å få en enkel oversikt over endokrinologiske sykdommer og begreper.

Etter et kort generelt kapittel om endokrinologi gjennomgår forfatterne endokrinologiske sykdommer i organbaserte kapitler og kapitler som omhandler diabetes mellitus, kalsium og beinrelaterte sykdommer, overvekt, hirsutisme og multippel endokrin neoplasi (MEN). Boken er i paperback og har oversiktlige illustrasjoner og fotografier for mange av de viktigste endokrinologiske reguleringssløyfene og sammenhengene. Særlig diabetes mellitus har fått mye oppmerksomhet med omtrent 50 sider.

Jeg tror at boken vil fungere bra for den målgruppen den er tiltenkt.

For fastleger og leger som jobber på medisinske avdelinger som behandler eller følger opp pasienter med endokrinologiske problemstillinger, kreves det dog en dypere tilnærming. Særlig avsnittene som omtaler behandlingen er i noen kapitler såpass korte at det kan være vanskelig å forstå konsekvensene av forskjellige behandlingsalternativer.

For den som leter etter en innføring i endokrinologi, anbefaler jeg også den norske læreboken i endokrinologi, som er et utmerket valg (1).

\section{Oskar Kelp}

Endokrinolog, Akershus universitetssykehus

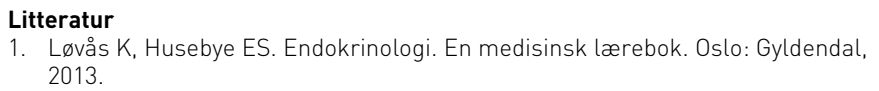

